\title{
Trial Element End Rule
}

National Cancer Institute

\section{Source}

National Cancer Institute. Trial Element End Rule. NCI Thesaurus. Code C83441.

An axiom that indicates a trial element has concluded. 